\title{
Variation in the UCP2 and UCP3 genes associates with abdominal obesity and serum lipids: The Finnish Diabetes Prevention Study
} Titta Salopuro*1, Leena Pulkkinen ${ }^{1}$, Jaana Lindström², Marjukka Kolehmainen ${ }^{1}$, Anna-Maija Tolppanen ${ }^{1}$, Johan G Eriksson ${ }^{2,3,4}$, Timo T Valle2, Sirkka Aunola ${ }^{5}$, Pirjo Ilanne-Parikka ${ }^{6,7}$, Sirkka KeinänenKiukaanniemi ${ }^{8}$, Jaakko Tuomilehto ${ }^{2,9,10}$, Markku Laakso ${ }^{11}$ and Matti Uusitupa ${ }^{1,12}$

Address: ${ }^{1}$ University of Kuopio, Department of Clinical Nutrition and Food and Health Research Center, Kuopio, Finland, ${ }^{2}$ National Public Health Institute, Department of Health Promotion and Chronic Disease Prevention, Diabetes Unit, Helsinki, Finland, ${ }^{3}$ University of Helsinki, Department of General Practice and Primary Health Care, Helsinki, Finland, ${ }^{4}$ Vasa Central Hospital, Vasa, Finland, ${ }^{5}$ National Public Health Institute, Department of Health and Functional Capacity, Laboratory for Population Research, Turku, Finland, ${ }^{6}$ Diabetes Center, Finnish Diabetes Association, Tampere, Finland, ${ }^{7}$ Tampere University Hospital, Science Center, Pirkanmaa Hospital District, Tampere, Finland, ${ }^{8}$ University of Oulu, Department of General Practice, Oulu, Finland, ${ }^{9}$ University of Helsinki, Department of Public Health, Helsinki, Finland, ${ }^{10}$ South Ostrobothnia Central Hospital, Seinäjoki, Finland, ${ }^{11}$ University of Kuopio, Department of Medicine, Kuopio, Finland and ${ }^{12}$ Kuopio University Hospital, Department of Medicine, Kuopio, Finland

Email: Titta Salopuro* - titta.salopuro@uku.fi; Leena Pulkkinen - leena.pulkkinen@uku.fi; Jaana Lindström - jaana.lindstrom@thl.fi; Marjukka Kolehmainen - marjukka.kolehmainen@uku.fi; Anna-Maija Tolppanen - anna-maija.tolppanen@uku.fi; Johan G Eriksson - johan.eriksson@thl.fi; Timo T Valle - timo.valle@thl.fi; Sirkka Aunola - sirkka.aunola@thl.fi; Pirjo IlanneParikka - pirjo.ilanneparikka@diabetes.fi; Sirkka Keinänen-Kiukaanniemi - skk@sun3.oulu.fi; Jaakko Tuomilehto - jaakko.tuomilehto@thl.fi; Markku Laakso - markku.laakso@kuh.fi; Matti Uusitupa - matti.uusitupa@uku.fi

* Corresponding author

Published: 21 September 2009

BMC Medical Genetics 2009, 10:94 doi:10.1 186/147/-2350-10-94
Received: 25 March 2009

Accepted: 21 September 2009

This article is available from: http://www.biomedcentral.com/I47I-2350/I0/94

(C) 2009 Salopuro et al; licensee BioMed Central Ltd.

This is an Open Access article distributed under the terms of the Creative Commons Attribution License (http://creativecommons.org/licenses/by/2.0), which permits unrestricted use, distribution, and reproduction in any medium, provided the original work is properly cited.

\begin{abstract}
Background: We explored the associations of three variants in the uncoupling protein 2 (UCP2) gene, one variant in the UCP2-UCP3 intergenic region and five variants in the uncoupling protein 3 (UCP3) gene with obesity and diabetes related traits in subjects with impaired glucose tolerance participating in Finnish Diabetes Prevention Study. Altogether 507 overweight individuals (body mass index: $31.2 \pm 4.5 \mathrm{~kg} / \mathrm{m}^{2}$, age: $55 \pm 7$ years) for whom DNA was available were randomized to either an intensified diet and physical activity group or to a conventional care control group.

Methods: We analysed the data from the baseline and annual follow-up visits from years I, 2 and 3. Measurements of anthropometry, plasma glucose and serum insulin in oral glucose tolerance test, serum total cholesterol, HDL-cholesterol and triglycerides were included. The median followup time for type 2 diabetes incidence was 7 years. Genetic variants were screened by restriction fragment length polymorphism or Illumina method.

Results: UCP3 gene variant rs378/907 was associated with increased serum total and LDLcholesterol levels, at baseline and during the follow-up period. The same variant was associated with a higher risk of type 2 diabetes. Variants $r$ / 726745 , rs / / 235972 and $r$ / $/ 800849$ in the UCP3 gene associated with serum total and LDL-cholesterol at baseline. Haploblock including variants rs659366, rs653529, rs /5763, and rs / 726745 was associated with measures of abdominal obesity
\end{abstract}


at baseline and in the longitudinal analysis. The haplotype comprising alleles rs659366-G, rs653529$A$, rs/5763-G and rs/726745-A was associated with higher waist-to-hip ratio, and haplotype comprising alleles rs378/907-G, rs / /235972-A, and rs/800849-T was associated with increased serum total and LDL-cholesterol concentrations.

Conclusion: Genetic variation in the UCP2-UCP3 gene cluster may act as a modifier increasing serum lipid levels and indices of abdominal obesity, and may thereby also contribute to the metabolic aberrations observed in obesity and type 2 diabetes.

\section{Background}

UCP2 is a member of the mitochondrial inner membrane carrier family that is expressed in a wide variety of tissues, for example in adipose tissue, skeletal muscle and pancreatic islets. The function of UCP2 is tissue-dependent, and its potential roles include the regulation of fat metabolism directly and indirectly, e.g. via effects on insulin secretion [1]. It also has a role in the limitation of reactive oxygen species (ROS) and macrophage-mediated immunity [2]. Recent studies have established UCP2 as a key component of beta cell glucose sensing, since it seems to regulate glucose-stimulated insulin secretion $[1,3]$, and is also a critical link between obesity, beta cell dysfunction and type 2 diabetes (T2DM) [4]. UCP2 and UCP3 genes are located on chromosome $11 \mathrm{q} 13$ adjacent to one another $[5,6]$. In a recent meta-analysis of genome-wide linkage studies, suggestive evidence for chromosome 11q13.3-22.3 was observed for body mass index (BMI) -defined obesity [7].

There are three common variants in the UCP2 gene, one located in the promoter region (-866 GA, rs659366), one is a missense variant in exon 4 (Ala55Val, CT, rs660339), and one locates in the untranslated exon 8 (45 bp DelIns in the 3'UTR). Their association with traits related to obesity, energy expenditure or T2DM remains controversial due to inconsistent findings [8-19]. Studies on $r 5659366$ have demonstrated associations between the $A$ allele and enhanced adipose tissue mRNA expression and decreased risk of obesity [17], increased energy expenditure [20], reduced beta cell function and higher risk of T2DM [14], lower insulin secretion [15], decreased lipid oxidation [16], increased preclinical atherosclerosis in women [21], and increased coronary heart disease risk [18]. Krempler et al. [14] have shown that the functional rs659366 variant, located in a multifunctional cis-regulatory site, acts as a binding site for a pancreatic transcription factor PAX6. Wang et al. [13] found that the heterozygous combination of the three variants (-866 GA, Val55Val, DelIns) was associated with increased BMI, triglyceride and fasting insulin levels.

While the UCP2 gene is expressed in almost all tissues, expression of the UCP3 gene is mostly restricted to skeletal muscle and brown adipose tissue. Suggested functions of UCP3 include regulation of fatty acid metabolism, redox state, and ROS formation [22,23]. UCP3 seems to be involved in the protection of mitochondria against lipotoxicity [24]. The human UCP3 gene gives rise to two main alternative transcripts, the shorter one having a polyadenylation site in intron 6 , which terminates approximately $50 \%$ of the transcripts. Therefore, human UCP3 exists as long (UCP3L) and short (UCP3S) forms [19]. A promoter region variant -55 CT (rs1800849) is potentially interesting since it is located only $6 \mathrm{bp}$ apart from the TATA box and 4 bp from a DR1 site, which is a part of a retinoic acid response element [25]. In Pima Indians the rs1800849-T allele increased UCP3 mRNA expression in skeletal muscle compared with the $C$ allele [25], and the expression level correlated negatively with BMI [26]. A direct correlation between sleeping metabolic rate and $24 \mathrm{~h}$ energy expenditure and the expression of UCP3 mRNA was also found in Pima Indians [26]. Moreover, the rs1800849-T allele was associated with higher waist-to-hip ratio (WHR) [27], decreased risk of T2DM, and atherogenic lipid profile [28], but associations with BMI were controversial [29-32]. No association between rs1800849 and body weight was seen in several studies [25,33-36].

The aim of this study was to assess the impact of five previously unexplored variants in addition to the four abovementioned known genetic variants in the UCP2-UCP3 gene cluster, either individually or as haplotypes, on obesity and T2DM related traits. The study subjects with impaired glucose tolerance (IGT) were prospectively followed in the Finnish Diabetes Prevention Study (DPS) $[37,38]$.

\section{Methods \\ Subjects and research design}

The DPS is a randomised, controlled, multicenter study carried out in Finland in 1993-2000. The DPS study design and methods used have been reported in detail elsewhere [37-39]. The main inclusion criteria were BMI over $25 \mathrm{~kg} / \mathrm{m}^{2}$, age 40 to 64 years, IGT based on the mean values of two oral glucose tolerance tests (OGTTs). A total of 522 individuals with IGT were randomised into either a control group or an intensive, individualised diet and physical exercise intervention group stratified according to the clinic, sex, and the mean plasma glucose concentra- 
tion two hours after an oral glucose load (7.8 to 9.4 or 9.5 to $11.0 \mathrm{mmol} / \mathrm{l})$. DNA was available from 507 individuals (166 men and 341 women). Their mean BMI was $31.2 \pm$ $4.5 \mathrm{~kg} / \mathrm{m}^{2}$ and age $55.3 \pm 7.1$ years. At the baseline, $5 \%$ of the individuals were using cholesterol lowering medication. The study protocol was approved by the Ethics Committee of the National Public Health Institute in Helsinki, Finland, and the study participants gave written informed consent. We certify that all applicable institutional and governmental regulations concerning the ethical use of human volunteers were followed during this research.

\section{Measurements}

A medical history was taken and a physical examination done at baseline and at each annual follow-up visit [38]. In this study, measurements from baseline to the 3-year examination were used, including height, weight, waist circumference (WC), hip circumference, serum lipid levels, and 2 h OGTT with glucose and insulin levels before (0 min) and after a $75 \mathrm{~g}$ glucose load (120 min) [38]. Plasma glucose was measured at each centre by standard methods. The serum insulin concentration was measured in a central laboratory by a radioimmunoassay method (Pharmacia, Uppsala, Sweden). The intra-assay coefficient of variation was $5.3 \%$ and the interassay coefficient of variation was $7.6 \%$. Homeostasis model for insulin resistance (HOMA-IR) was calculated using the formula: fasting plasma glucose $(\mathrm{mmol} / \mathrm{l}) \times$ fasting serum insulin $(\mathrm{mU} / \mathrm{l}) / 22.5$, and homeostasis model for insulin secretion (HOMA-IS) was calculated as $20 \times$ fasting serum insulin $(\mathrm{mU} / \mathrm{l}) /($ fasting plasma glucose $[\mathrm{mmol} / \mathrm{l}]$ - 3.5) [40]. Serum levels of total cholesterol, high-density lipoprotein (HDL) cholesterol and triglycerides were measured by enzymatic assay in the central laboratory in Helsinki. Formula of Friedewald [41] was used to calculate the concentration of low density lipoprotein (LDL) cholesterol.

\section{DNA analysis}

The single nucleotide polymorphisms (SNP) for genotype analysis were selected from the region spanning the UCP2 and UCP3 genes ( $34.4 \mathrm{~kb})$ by using the International HapMap database and Tagger software [42] http:// www.broad.mit.edu/mpg/tagger/server.html. Rs660339, rs659366, and rs1800849 were forced in the selection procedure. The SNPs covered $86.2 \%$ of the genetic information of the studied region ( $\mathrm{r} 2>0.8)$. It should be noted that the DelIns variant of the UCP2 gene is not included in the database, since it is not a SNP but a 45 bp insertion.

The rs659366 and rs660339 variants of the UCP2 gene and the rs1800849 variant of the UCP3 gene were screened by the restriction fragment length polymorphism after digestion with MluI, HincII and HaeIII, respectively, with minor modifications to previously described methods $[9,15,43]$.
The DelIns variant of the UCP2 gene was analysed by gel electrophoresis of the PCR-product. The intergenic region variant rs653529 and four variants locating in the UCP3 gene (rs15763, rs1726745, rs3781907, rs11235972) were genotyped by using the custom Golden Gate genotyping reagents and consumables (Illumina Inc, San Diego, CA). Only 501 (rs1726745) or 502 (rs653529, rs15763, rs3781907, rs11235972) subjects were successfully genotyped by Illumina. For other variants, $n=507$.

\section{Statistical analysis}

The data were analysed using the SPSS/WIN program version 14.0 (SPSS, Chigago, IL, USA). The normality of distributions of study variables was evaluated with the Kolmogorov-Smirnov test with Lilliefors' correction, and appropriate transformation was used when necessary. For variables with skewed distribution, Kruskal-Wallis test was used. Univariate analysis of variance was used to compare the effect of the gene variants on continuous variables. Adjustment for age, gender and BMI was done, when appropriate. In addition, serum lipoprotein and lipid concentrations were adjusted for the use of cholesterol-lowering medication as well. Chi square test was used in comparison of categorical variables. The relative changes in HOMA-IS from baseline to three years were calculated as follows: [(parameter 3 -year - parameter $_{\text {baseline }}$ )/parameter $\left._{\text {baseline }}\right] \times 100 \%$. Longitudinal changes were examined using repeated measures of General Linear Model. Homogeneity of variances was tested using Levene's test. Cox regression analysis, adjusted for the study group, baseline weight, weight change and baseline fasting plasma glucose, was performed to evaluate whether the gene variants predicted the development of T2DM.

Linkage disequilibrium (LD) statistics were calculated by Haploview software [44] and haplotype analysis was done by THESIAS 3.1 [45] http://ecgene.net/genecanvas, which is based on the stochastic-EM algorithm. Haplotype analyses of the quantitative variables were adjusted for age, gender and BMI, when appropriate. The survival analysis for haplotypes was adjusted for the study group, baseline weight, weight change and baseline fasting plasma glucose.

A $p$-value $<0.05$ was considered statistically significant. Correction for multiple hypothesis testing was performed with false discovery rate (FDR) using Q-value 1.0 software. $\pi_{0}$ was estimated with bootstrap method [46] using $\lambda$ range from 0 to 0.9 by 0.05 . Due to the distribution of $p$-values, the $\lambda$ was set to 0 for correcting the results of Cox regression. Essentially, this is a conservative way of calculating FDR and thereby produces the estimate implicit in the Benjamini and Hochberg methodology. In text, $q$ stands for FDR, and is reported for each $p<0.05$ and should be interpreted as minimum FDR that is incurred 
when calling that test significant. Data are given as means $\pm \mathrm{SD}$, unless otherwise indicated.

\section{Results}

\section{Genotype and allele frequencies and LD}

The genotype frequencies of the nine gene variants were consistent with the Hardy-Weinberg equilibrium ( $p$-values ranging from 0.065 to 0.952 ), and did not differ between the study groups. Location of the variants in the UCP2 and UCP3 genes and their minor allele frequencies and LD statistics ( $D^{\prime}$ and $r^{2}$ ) are presented in Figure 1 and Table 1. D' values were between 0.053 and 1.0, whereas $\mathrm{r}^{2}$ varied from 0.002 to 0.979 . Although variants $r s 11235972$ and rs1800849 were in strong linkage disequilibrium (D' $=1.0$ and $\mathrm{r}^{2}=0.979$ ), no completely redundant variants were observed; thus all nine variants were included in subsequent association analysis. Based on solid spine of LD, haplotype analysis was done separately for three haplotype blocks, block 1 including Delins and rs660339 variants of the UCP2 gene, block 2 including rs659366, rs653529, rs15763 and rs1726745 of the UCP2 and UCP3 genes, and block 3 covering variants rs3781907, rs11235972 and rs1800849 of the UCP3 gene.

\section{Baseline characteristics of subjects}

No significant differences were observed among the genotypes regarding body weight, BMI, fasting and 2-h insulin levels, HOMA-IR or HOMA-IS. Fasting and 2-h glucose levels differed among the rs660339 genotypes ( $p / q$ 0.006/ 0.006 and $0.025 / 0.010$, respectively), and among the rs659366 genotypes ( $p / q 0.007 / 0.006$ and $0.025 / 0.010$, respectively). Specifically, the rs660339-CC and rs659366$A A$ homozygotes had the highest fasting glucose concentrations and the rs660339-CC and rs659366-GG homozygotes had the highest $2-\mathrm{h}$ glucose concentrations. In addition, rs653529 associated with 2-h glucose level, so that the individuals with $A A$-genotype had the highest val- ues $(p / q 0.028 / 0.010)$, but the associations with glucose were not dependent on the allele dosage.

Four gene variants in the haploblock 2 associated with indices of abdominal obesity, namely WC, WHR and waist-to-height ratio (WHtR). Rs659366, rs653529, rs15763 and rs1726745 associated with WHR at baseline ( $p / q 0.048 / 0.014,0.009 / 0.006,0.018 / 0.010$ and $0.031 /$

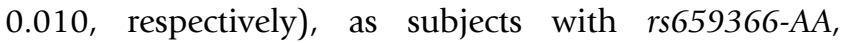
rs653529-GG, rs15763-AA and rs1726745-GG genotypes had the lowest WHR (Table 2). Although less consistent, associations were also seen between these variants and WC and WHtR. WC was associated with rs659366, rs653529 and rs1726745, whereas WHtR was associated with $r s 653529, r s 15763$ and $r s 1726745$ (Table 2). Also the DelIns variation in UCP2 associated with WHR, subjects with the DelDel genotype having the highest WHR at baseline $(p / q 0.017 / 0.256)$.

Rs1726745, rs3781907, rs11235972 and rs1800849 were associated with serum total cholesterol and LDL-cholesterol levels. Subjects with rs1726745-GG, rs3781907-GG, rs11235972-AA and rs1800849-TT genotypes had the highest serum total cholesterol concentrations among the variants $(p / q 0.022 / 0.010,0.005 / 0.006,0.032 / 0.010$ and $0.050 / 0.014$, respectively), as well as serum LDL-cholesterol $(p / q 0.005 / 0.006,0.004 / 0.006,0.045 / 0.014$ and $0.071 / 0.018$, respectively). Moreover, the total cholesterol-to-HDL-cholesterol ratio was highest for the subjects with $r s 3781907-G G$ genotype ( $p / q$ 0.045/0.013). Baseline characteristics of the DPS subjects according to $r s 3781907$ are presented in the Table 3. Regarding rs3781907 and rs11235972, the results on lipids and lipoproteins remained unchanged, if the individuals using cholesterol lowering medication $(n=25)$ were excluded from the analyses. Regarding $r s 1726745$, and $r s 1800849$, the results were statistically significant only for rs1726745 associa-

Table I: Pairwise linkage disequilibrium, presented as $D^{\prime}$ and $r^{2}$ values, among the nine variants in UCP2 and UCP3 genes (haploblocks are shown bolded)

SNP ID $\quad$ D'

\begin{tabular}{|c|c|c|c|c|c|c|c|c|c|c|}
\hline & Dellns & rs660339 & rs659366 & rs653529 & rs/5763 & rs 1726745 & rs3781907 & rs I/ 235972 & rs/800849 \\
\hline$r^{2}$ & $\begin{array}{l}\text { Dellns } \\
(0.297)\end{array}$ & & 0.977 & 0.684 & 0.630 & 0.906 & 0.402 & 0.829 & 0.856 & 0.857 \\
\hline & rs660339 CT (0.470) & $0.45 I$ & & 0.985 & 0.912 & 0.862 & 0.548 & 0.282 & 0.056 & 0.053 \\
\hline & $r s 659366$ GA (0.403) & 0.292 & 0.736 & & 0.952 & 0.867 & 0.844 & 0.218 & 0.133 & 0.134 \\
\hline & $r s 653529$ AG (0.4I5) & 0.236 & 0.663 & 0.863 & & 0.902 & 0.805 & 0.243 & 0.119 & 0.125 \\
\hline & $r s / 5763$ GA $(0.218)$ & 0.542 & 0.232 & 0.309 & 0.318 & & 1.0 & 0.871 & 0.934 & 0.933 \\
\hline & $r s / 726745$ GA (0.403) & 0.046 & 0.181 & 0.325 & 0.311 & 0.188 & & 0.756 & 0.948 & 0.940 \\
\hline & $r s 3781907$ AG (0.327) & 0.140 & 0.034 & 0.016 & 0.020 & 0.102 & 0.189 & & 0.804 & 0.807 \\
\hline & $r s / I 235972$ GA (0.37I) & 0.181 & 0.002 & 0.015 & 0.012 & 0.142 & 0.358 & 0.535 & & 1.0 \\
\hline & rs / 800849 CT (0.377) & 0.185 & 0.002 & 0.016 & 0.013 & 0.145 & 0.360 & 0.527 & 0.979 & \\
\hline
\end{tabular}

Major/minor alleles, and the frequencies of the minor alleles of the corresponding variants are indicated next to each variant identification number 


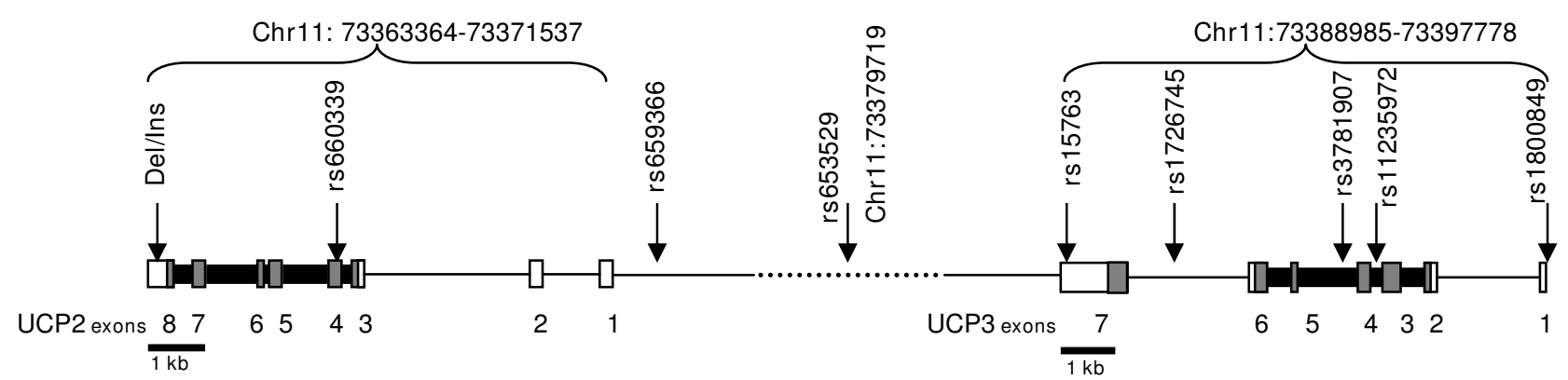

Figure I

Schematic representation of the UCP2 and UCP3 genes indicating the locations of the analysed variants. Grey boxes, coding region; white boxes, UTR; dotted line, intergenic region of $\sim 17 \mathrm{~kb}$.

tion with LDL-cholesterol, if the individuals using cholesterol lowering medication were excluded.

\section{The 3-year changes}

Longitudinal analysis of WHR showed that subjects with rs653529-GG, rs15763-AA and rs1726745-GG genotypes had the lowest WHR throughout the 3-year follow-up $(p /$ $q 0.025 / 0.030,0.039 / 0.030$ and $0.035 / 0.030$, respectively) (Figure 2). Longitudinal analyses of WC and WHtR showed similar results, with WC being associated with rs15763 ( $p / q 0.030 / 0.030)$ and WHtR associating with $r s 15763$ and $r s 1726745$ ( $p / q$ 0.009/0.030, 0.040/0.030, respectively).

Longitudinal changes in serum cholesterol levels were associated with rs3781907-AA genotype having the lowest total cholesterol ( $p / q 0.020 / 0.030)$ and LDL-cholesterol
( $p / q 0.010 / 0.030)$ throughout the years 0-3 (Figure 3). Subjects with $r s 3781907-A A$ genotypes also had the lowest serum triglyceride levels, but this was seen only in the control group ( $p / q 0.039 / 0.030)$. HDL-cholesterol level was lowest among the subjects with rs3781907-GG genotype in the intervention group $(p / q 0.041 / 0.030)$. Furthermore, the total cholesterol-to-HDL cholesterol ratio was highest among subjects with the rs3781907-GG genotype in the entire DPS ( $p / q$ 0.015/0.030). All these results remained significant if the individuals using cholesterol lowering medication were excluded.

The 3-year change in HOMA-IS was associated similarly with all three UCP2 variants (DelIns, rs660339, rs659366), the intergenic region variant $r s 653529$ and UCP3 variant rs15763, showing increased values for wild-type subjects, intermediate for heterozygous and the lowest values for

Table 2: Associations of representative SNPs in the UCP2-UCP3 gene region with indices of abdominal obesity at the baseline

\begin{tabular}{|c|c|c|c|c|c|c|}
\hline \multirow[b]{2}{*}{ SNP } & \multirow[b]{2}{*}{ Obesity index } & \multicolumn{3}{|c|}{ Genotype } & \multirow[b]{2}{*}{$p^{\mathbf{a}}$} & \multirow[b]{2}{*}{$\boldsymbol{q}$} \\
\hline & & Homozygous for the common allele & Heterozygous & Homozygous for the rare allele & & \\
\hline \multirow[t]{3}{*}{ rs659366 } & WC, cm & $102 \pm 11$ & $101 \pm 11$ & $100 \pm 11$ & 0.033 & 0.010 \\
\hline & WHR & $0.93 \pm 0.07$ & $0.92 \pm 0.07$ & $0.91 \pm 0.08$ & 0.048 & 0.014 \\
\hline & WHtR & $0.61 \pm 0.06$ & $0.61 \pm 0.06$ & $0.61 \pm 0.07$ & 0.119 & 0.027 \\
\hline \multirow[t]{3}{*}{ rs653529 } & WC, $\mathrm{cm}$ & $102 \pm 11$ & $101 \pm 11$ & $100 \pm 11$ & 0.011 & 0.007 \\
\hline & WHR & $0.93 \pm 0.07$ & $0.92 \pm 0.07$ & $0.91 \pm 0.08$ & 0.009 & 0.006 \\
\hline & WHtR & $0.61 \pm 0.06$ & $0.61 \pm 0.06$ & $0.60 \pm 0.07$ & 0.022 & 0.010 \\
\hline \multirow[t]{3}{*}{ rs 15763} & WC, $\mathrm{cm}$ & $102 \pm 11$ & $100 \pm 10$ & $100 \pm 12$ & 0.075 & 0.019 \\
\hline & WHR & $0.92 \pm 0.07$ & $0.92 \pm 0.07$ & $0.90 \pm 0.07$ & 0.018 & 0.010 \\
\hline & WHtR & $0.61 \pm 0.07$ & $0.60 \pm 0.06$ & $0.60 \pm 0.07$ & 0.024 & 0.010 \\
\hline \multirow[t]{3}{*}{ rs I 726745} & WC, cm & $100 \pm 11$ & $102 \pm 11$ & $102 \pm 11$ & 0.008 & 0.006 \\
\hline & WHR & $0.91 \pm 0.08$ & $0.92 \pm 0.07$ & $0.93 \pm 0.07$ & 0.031 & 0.010 \\
\hline & WHtR & $0.60 \pm 0.06$ & $0.62 \pm 0.06$ & $0.61 \pm 0.07$ & 0.003 & 0.006 \\
\hline
\end{tabular}

Data are means \pm SD

aUnivariate ANOVA, adjusted for age, gender, BMI

WC, waist circumference; WHR, waist-to-hip ratio; WHtR, waist-to-height ratio 
Table 3: Baseline characteristics and conversion to type 2 diabetes (T2DM) according to the genotypes of SNP rs378 I907 at UCP3 gene

\begin{tabular}{|c|c|c|c|c|c|}
\hline & \multicolumn{3}{|c|}{ Genotype } & \multirow[b]{2}{*}{$p^{\mathbf{b}}$} & \multirow[b]{2}{*}{$q$} \\
\hline & $A A$ & AG & GG & & \\
\hline$n(M / F)^{a}$ & $221(73 / 148)$ & $233(79 / 154)$ & $48(13 / 35)$ & 0.645 & 0.714 \\
\hline Age (years) & $56 \pm 7$ & $55 \pm 7$ & $53 \pm 7$ & $0.077^{c}$ & 0.421 \\
\hline Weight (kg) & $86.3 \pm 14.6$ & $85.8 \pm 13.5$ & $87.3 \pm 15.9$ & 0.878 & 0.924 \\
\hline BMI $\left(\mathrm{kg} / \mathrm{m}^{2}\right)$ & $31.3 \pm 4.8$ & $31.1 \pm 4.2$ & $31.6 \pm 5.2$ & 0.991 & 0.954 \\
\hline Waist-to-hip ratio & $0.92 \pm 0.07$ & $0.92 \pm 0.07$ & $0.93 \pm 0.08$ & 0.583 & 0.067 \\
\hline Fasting plasma glucose (mmol/l) & $6.2 \pm 0.8$ & $6.1 \pm 0.7$ & $6.2 \pm 0.7$ & 0.295 & 0.047 \\
\hline Fasting serum insulin (pmol/l) & $85 \pm 40$ & $92 \pm 51$ & $86 \pm 30$ & $0.665^{c}$ & 0.070 \\
\hline Serum total cholesterol ( $\mathrm{mmol} / \mathrm{l})$ & $5.5 \pm 0.9$ & $5.7 \pm 0.9$ & $5.9 \pm 1.0$ & 0.005 & 0.006 \\
\hline Serum LDL-cholesterol $(\mathrm{mmol} / \mathrm{l})$ & $3.5 \pm 0.8$ & $3.7 \pm 0.8$ & $3.9 \pm 1.0$ & 0.004 & 0.006 \\
\hline Serum HDL-cholesterol (mmol/l) & $1.22 \pm 0.29$ & $1.22 \pm 0.30$ & $1.17 \pm 0.25$ & 0.834 & 0.081 \\
\hline Serum triglycerides (mmol/l) & $1.69 \pm 0.73$ & $1.74 \pm 0.83$ & $1.81 \pm 0.70$ & 0.558 & 0.066 \\
\hline Total cholesterol-to-HDL-cholesterol ratio & $4.73 \pm 1.22$ & $4.90 \pm 1.26$ & $5.15 \pm 1.15$ & 0.045 & 0.013 \\
\hline Converters to T2DM (n/\%)a & $72 / 33 \%$ & $89 / 38 \%$ & $23 / 48 \%$ & 0.039 & 0.394 \\
\hline
\end{tabular}

Data are means \pm SD

a $\chi^{2}$ test

b Univariate ANOVA, adjusted for age and sex (anthropometric measurements), for age, sex and BMI (glucose, insulin), or for age, sex, BMI, and the use of cholesterol lowering medication (lipids)

c Kruskal-Wallis test

homozygous subjects ( $p / q \quad 0.004 / 0.304,0.016 / 0.325$, $0.037 / 0.325,0.018 / 0.325$ and $0.016 / 0.325$, respectively), whereas no association with other four UCP3 variants was found.

\section{Haplotype analysis}

In order to confirm the associations with serum lipids and WHR, haplotype analysis was performed separately for blocks 1, 2, and 3. Only the haplotypes with frequency $\geq$ 0.05 were included in the analysis; thus, block 1 consisted of 3 haplotypes (DelC, InsT, and DelT), block 2 of 4 haplotypes (GAGA, GAGG, AGAG, and AGGG) and block 3 of 3 different haplotypes (AGC, GAT, and AAT) (Table 4).

In block 2 the haplotype AGAG showed lower WHR at baseline when compared with the reference haplotype GAGA ( $p=0.050)$. In block 3 the haplotype GAT had higher serum total cholesterol $(p=0.006)$ and LDL-cholesterol ( $p=0.024)$ at baseline when compared with the reference haplotype AGC. Moreover, the haplotype AAT showed a greater decrease (0-3 years) in LDL-cholesterol level compared with the reference haplotype AGC during the 3 -year follow-up ( $\mathrm{p}=0.037)$. No associations were seen for the haplotypes in the haploblock 1 .

\section{Conversion to T2DM}

During a median follow-up of seven years 185 individuals (75 in the intervention group and 110 in the control group) developed T2DM. The subjects with the rs3781907-G allele were at a higher risk for T2DM when compared with subjects with $A A$ genotype, with hazard ratio (HR) of 1.48 (95\%CI 1.09-2.00), p/q 0.011/0.100.
We also analysed the genotype $\times$ study group interaction for the diabetes conversion, but it was not statistically significant $(p=0.447)$. The percentage of subjects with $A A$ genotype converting to T2DM was $33 \%$, whereas it was $38 \%$ and $48 \%$ for the subjects with $A G$ and $G G$ genotypes, respectively ( $p / q 0.039 / 0.394)$ (Table 3$)$. The percentages of converters were similar for both study groups, with GG genotype showing the highest and $A A$ genotype showing the lowest percentages of converters.

Surprisingly, subjects in the intervention group carrying the UCP2 InsIns genotype were at a higher risk compared with subjects with Del allele, with HR 2.53 (95\%CI 1.115.73), $p / q 0.027 / 0.243$. Such a risk increment was not seen in the control group, nor in the entire DPS. No genotype $\times$ study group interaction was seen here either.

The conversion to T2DM during the follow-up did not differ significantly among the other gene variants. In the haplotype analysis, none of the haplotypes studied were associated with an increased risk of T2DM.

\section{Discussion}

In the present study we evaluated whether the UCP2 and UCP3 genes act as modifiers for obesity and diabetes related risk factors. This study provides new evidence concerning associations between genetic variations in the UCP2 and UCP3 genes and serum lipid concentrations as well as indices of abdominal obesity, both being characteristics of the metabolic syndrome. Previous studies have explored effects of these genes on various traits in several populations, with inconsistent results concerning associa- 

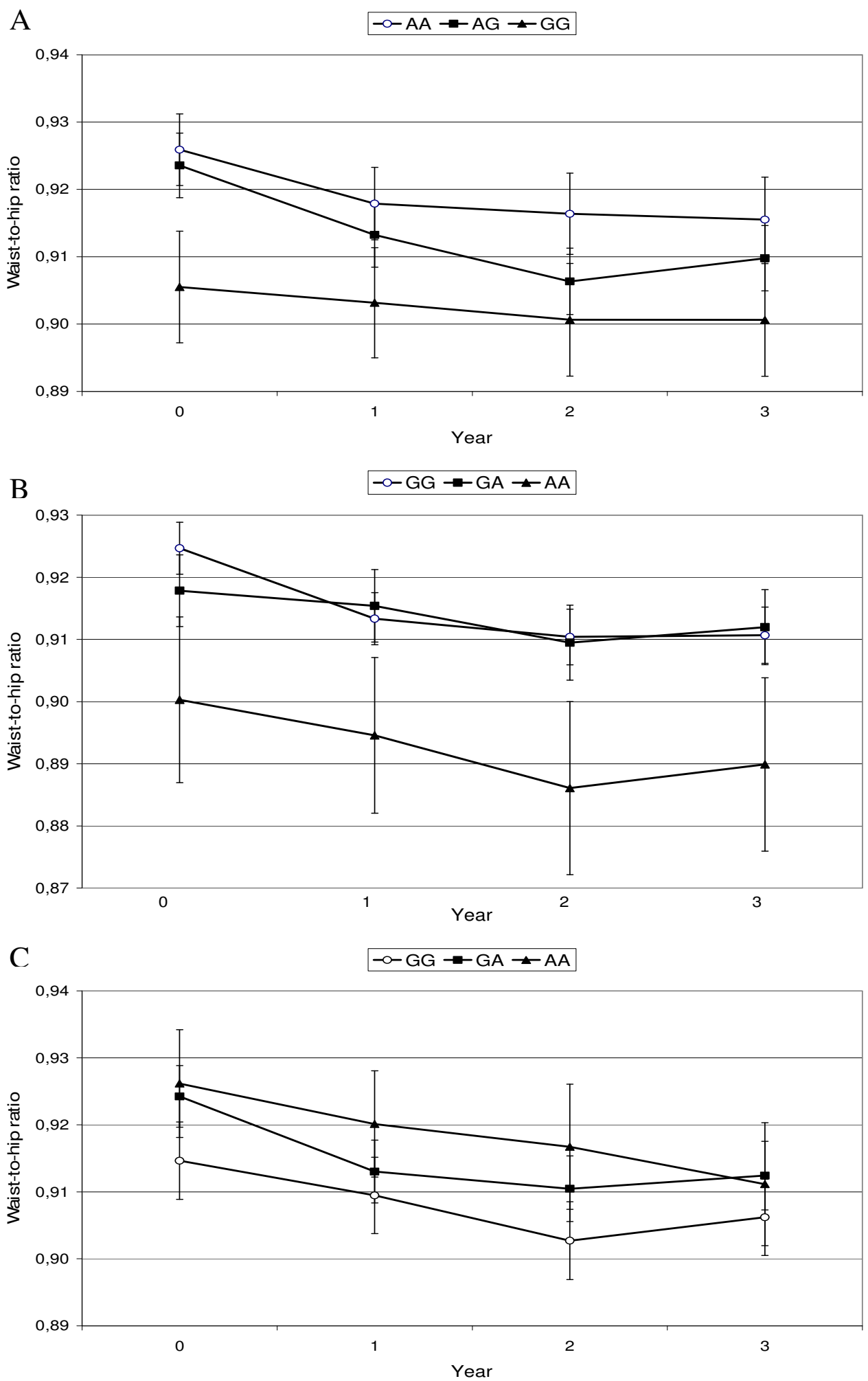

Figure 2

Waist-to-hip ratio from baseline to year 3 according to rs653529 (a), rs I 5763 (b), and rs I 726745 (c) variants, p/q

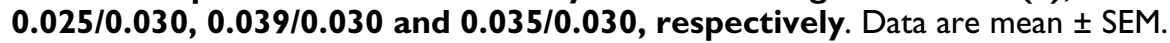


A

$\rightarrow-A A \rightarrow-A G \rightarrow G G$

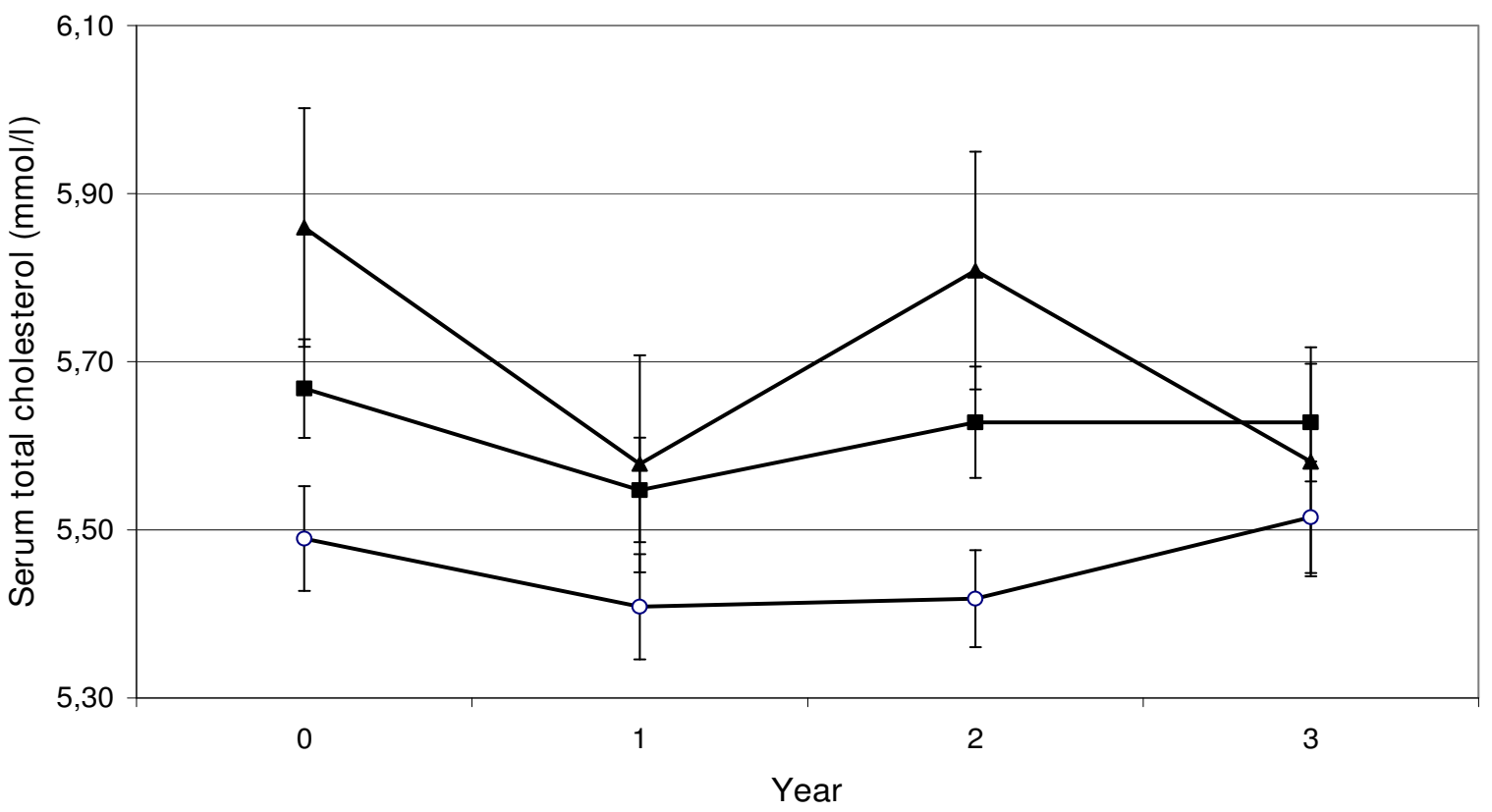

B

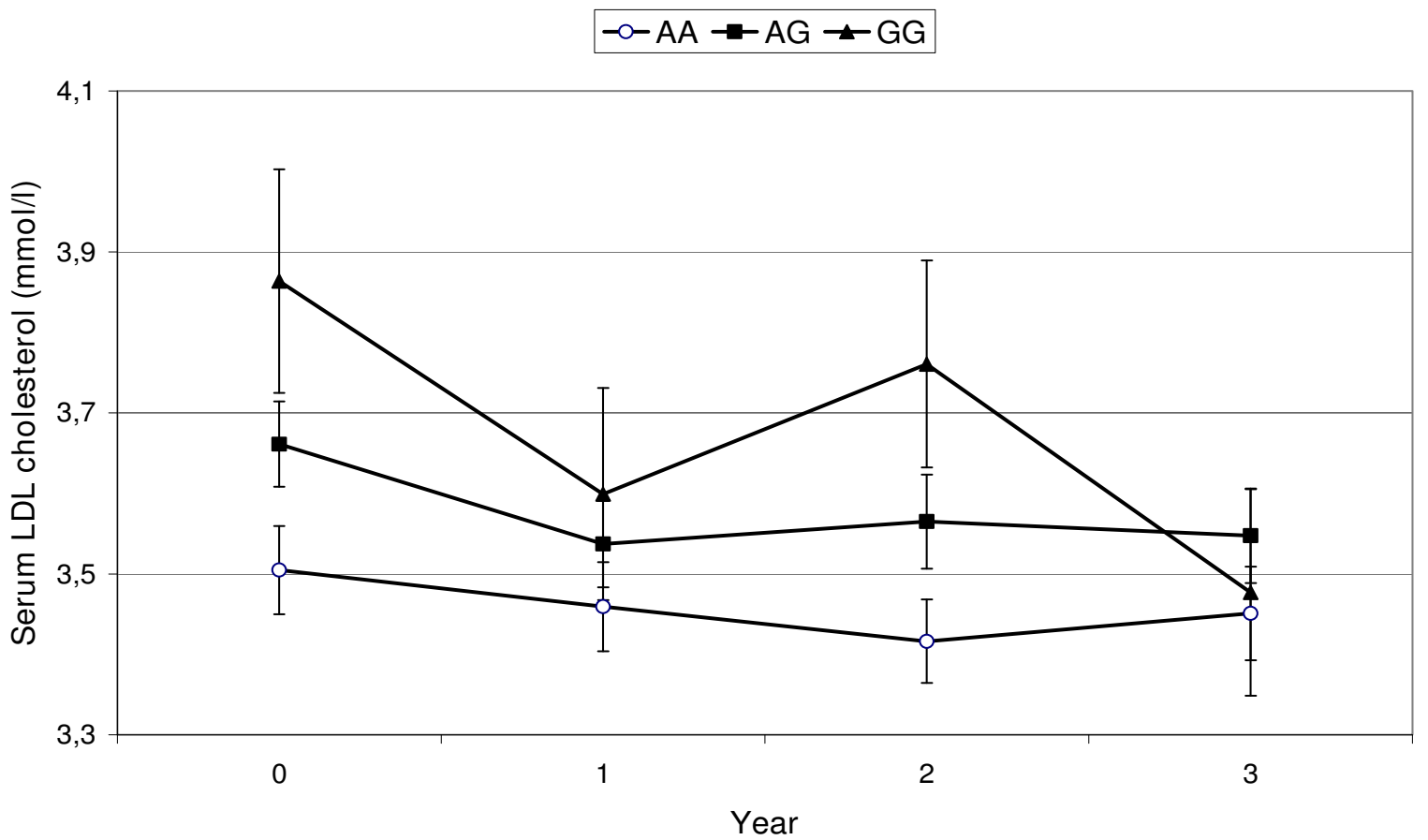

Figure 3

Serum total cholesterol (a) and LDL-cholesterol (b) levels, from baseline to year 3, according to rs378 I907 variant of the UCP3 gene, p/q $0.020 / 0.030$ and $0.010 / 0.030$, respectively. Data are mean \pm SEM. 
Table 4: Frequencies and associations of the major haplotypes (frequency $\geq 0.05$ ) of three haploblocks in the UCP2-UCP3 gene region

\begin{tabular}{|c|c|c|c|c|c|c|}
\hline \multirow{2}{*}{$\begin{array}{l}\text { Haploblock } \\
\text { Block I }\end{array}$} & \multicolumn{4}{|c|}{ Marker } & \multirow[t]{2}{*}{ Frequency } & \multirow[t]{2}{*}{ Association } \\
\hline & Dellns & rs660339 & & & & \\
\hline & Del & $C$ & & & $0.519 \mathrm{a}$ & NS \\
\hline & Ins & $T$ & & & 0.300 & NS \\
\hline & Del & $T$ & & & 0.177 & NS \\
\hline \multirow[t]{5}{*}{ Block 2} & rs659366 & rs653529 & rsI5763 & rsI726745 & & \\
\hline & $G$ & $A$ & $G$ & $A$ & $0.359 a$ & NS \\
\hline & $G$ & $A$ & $G$ & $G$ & 0.203 & NS \\
\hline & $A$ & $G$ & $A$ & $G$ & 0.202 & $\downarrow W H R, p=0.050^{b}$ \\
\hline & $A$ & $G$ & $G$ & $G$ & 0.175 & NS \\
\hline \multirow[t]{4}{*}{ Block 3} & rs3781907 & rsII 235972 & rsl800849 & & & \\
\hline & $A$ & $G$ & $C$ & & $0.584^{a}$ & NS \\
\hline & $G$ & $A$ & $T$ & & 0.288 & $\begin{array}{l}\uparrow \text { cholesterol, } p=0.006 \mathrm{c} \\
\uparrow \mathrm{LDL}, p=0.024^{\mathrm{c}}\end{array}$ \\
\hline & $A$ & $A$ & $T$ & & 0.084 & $\downarrow \Delta \mathrm{LDL}, p=0.037 \mathrm{c}$ \\
\hline
\end{tabular}

a The most frequent haplotype is the reference, with which the others are compared

${ }^{b}$ Adjusted for age and gender

cAdjusted for age, gender and BMI

$\uparrow$, higher in comparison with the reference haplotype; $\downarrow$, lower in comparison with the reference haplotype

Table 5: Associations of UCP2 and UCP3 gene variants with waist-to-hip ratio (WHR) and serum lipid concentrations in previous studies

\begin{tabular}{|c|c|c|c|c|c|}
\hline & Ref. & $\begin{array}{l}\text { Subjects } \\
\text { (number, ethnicity) }\end{array}$ & Variant & Risk allele & Association \\
\hline \multirow[t]{3}{*}{ WHR } & [43] & $\begin{array}{l}\text { 710, South Indian } \\
450, \text { Caucasoid }\end{array}$ & UCP3: rs/800849 & $T$ & Higher WHR \\
\hline & [27] & 162, Caucasoid & UCP3: rs/800849 & $T$ & Higher WHR \\
\hline & [34] & 460, Asian & $\begin{array}{l}\text { UCP3: haplotype } \\
\text { including rs } / 800849\end{array}$ & $C$ in haplotype CGTACC & Higher WHR \\
\hline \multirow[t]{5}{*}{ Lipids } & {$[28]$} & II75, Caucasoid & UCP3: rs/800849 & $T$ & $\begin{array}{l}\text { Higher total } \\
\text { and LDL-cholesterol conc. }\end{array}$ \\
\hline & [13] & 796, several & $\begin{array}{l}\text { UCP2: rs659366 } \\
\text { UCP2: rs660339 } \\
\text { UCP2: Del/Ins }\end{array}$ & $\begin{array}{l}\text { Heterozygous genotype combination GTII } \\
\text { ATD }\end{array}$ & $\begin{array}{l}\text { Higher triglyceride } \\
\text { concentration }\end{array}$ \\
\hline & [56] & 681, Caucasoid & UCP2: rs659366 & $A$ & $\begin{array}{l}\text { Higher } \\
\text { triglyceride, total } \\
\text { and LDL-cholesterol conc. }\end{array}$ \\
\hline & {$[55]$} & 658, Asian & $\begin{array}{l}\text { UCP2: } r s 659366 \\
\text { UCP2: } r s 660339\end{array}$ & $\begin{array}{l}A \\
T\end{array}$ & Lower HDL-cholesterol concentration \\
\hline & [32] & 282, Japanese & UCP3: rs/800849 & $C$ & Lower HDL-cholesterol concentration \\
\hline
\end{tabular}


tions with lipid levels and WHR/abdominal obesity (Table 5). The study subjects in the DPS were overweight with IGT, and thus at a high risk to develop T2DM. The advantages of this study population are i) homogenous, carefully selected and phenotyped subjects, ii) prospective study design with extensive longitudinal follow-up data on key variables, iii) confirmation of new T2DM diagnosis based upon two subsequent OGTTs, and iv) Finnish population with only few founding members and thus genetically relatively homogeneous. On the other hand, one drawback for genetic analyses in the DPS is the limited power due to relatively small sample-size, particularly if the analyses are carried out in smaller sub-groups. In this study, stratification to different groups was unnecessary, since the associations with WHR and lipid levels were observed in the entire DPS study population.

To our knowledge, this is the first study exploring effects of the gene variants rs653529, rs15763, rs1726745, rs3781907 and rs11235972 on several metabolic traits. Interestingly, subjects with rs3781907-G allele experienced a higher risk of T2DM and dyslipidemia compared with subjects homozygous for the common allele. The conversion to T2DM and serum levels of total cholesterol, LDL-cholesterol and total cholesterol-to-HDL-cholesterol ratio were modified by the dosage of $r s 3781907-G$ allele. The UCP3 promoter variant $r s 1800849$, which is located in the same haploblock and is in LD with rs3781907, has been previously shown to be associated with an increased [47] or decreased [28] risk of T2DM, increased skeletal muscle UCP3 mRNA expression [25], higher total, LDL[28] and HDL-cholesterol concentrations [32], higher [29] or lower BMI [30-32], higher WHR [27,43] and higher fat mass and lean mass [48]. In this study rs1800849 was associated with higher total cholesterol and LDL-cholesterol concentration at baseline, both as alleles and also as a member of the haploblock 3 , in line with findings from earlier studies [28]. Interestingly, all the haploblock 3 variants were associated with total and LDL-cholesterol at the baseline, although the most consistent association with various serum lipoprotein and lipid concentrations at baseline and longitudinally was seen for $r s 3781907$ that was also a risk factor for conversion to T2DM. FDR was low for these associations, which further provides support for our findings. However, as no previous studies with this variant exist, a confirmation of the present results is needed in other populations.

Although none of the gene variants were associated with weight or BMI, variants in the haploblock 2 associated with several indices of abdominal obesity at baseline (rs659366, rs653529, rs15763, rs1726745) and longitudinally (rs653529, rs15763, rs1726745). Although waist circumference and BMI are strongly correlated [49], WC, WHR and WHtR are all independent obesity-related pre- dictors of cardiovascular risk independent of BMI [50], and together with serum lipid concentrations they are simple clinical surrogate markers of excess visceral/ectopic fat [49]. In this study the genetic variation in UCP2-UCP3 gene cluster seemed to be also associated with both serum lipids and indices of abdominal obesity as well. The single-marker associations were mostly haploblock specific, so that the markers from haploblock 2 were associated with central obesity indices, whereas the markers from the haploblock 3 were associated with serum cholesterol concentrations. The results of haplotype analyses were in line with the results of single marker analyses, but they did not reveal a haplotype that would explain the associations substantially better than the individual markers. We conclude that rs1726745 explains most of the associations (both baseline and longitudinal) seen in haploblock 2 with central obesity, and rs3781907 explains most of the associations seen in haploblock 3 with total and LDL-cholesterol concentrations. However, it is difficult to suggest whether the causative variant truly is one of the studied markers or simply a SNP that is in complete disequilibrium with them.

As for the functional UCP2 promoter variant -866 GA ( $r s 659366$ ), previous studies have found that it is associated with a reduced prevalence of obesity [17], reduced risk of coronary artery disease [51], reduced [52] or increased [14] risk of T2DM, lower insulin secretion $[15,53]$, reduced insulin sensitivity [54], a decreased [13] or increased [17]UCP2 mRNA level in adipose tissue, higher oxidative stress and risk of coronary heart disease [18], decreased HDL-cholesterol [55], and increased serum triglyceride, total cholesterol and LDL-cholesterol levels [56]. In our study, the subjects with the rs659366-A allele had lower WC and WHR at baseline, compared with subjects with $G$ allele, both individually as well as a member of haploblock 2. Also the insulin secretion, measured by HOMA-IS, seemed to be decreased most in the subjects with rs659366-A allele during the 3-year follow-up, although no differences were seen at the baseline. These findings are in line with previous findings $[15,17,53]$. FDR was low for the associations with abdominal obesity indices thus supporting it, but high for the associations with HOMA-IS, which of course weakens the strength of this finding.

UCP2 has been said to act as adiposity angel and diabetes devil [57], whereas increased expression of UCP3 has been suggested to be associated with weight loss success [58]. The promoter area variant alleles in UCP2 (rs659366-A) and in UCP3 (rs1800849-T) have been shown to increase gene expression, and thus these alleles might protect against obesity. In our study the rs659366-A allele were associated with lower WHR and WC at baseline, in line with findings by Esterbauer et al. [17]. How- 
ever, no association between rs1800849 and obesity was seen in this study. Neither were the promoter area variants associated with risk of T2DM. This could be due to the relatively small study population, and also the genetic 'makeup' varies from one population to another. Furthermore, as the mean BMI of the study population was 31.2 $\mathrm{kg} / \mathrm{m}^{2}$, the 'obese character' may also have masked the effects of these genetic variants, which may explain the lack of association with obesity.

\section{Conclusion}

In summary, several novel findings were detected and they need to be confirmed. The subjects with the rs3781907-G allele had higher levels of serum total and LDL-cholesterol concentrations at baseline and at longitudinal follow-up, and a higher risk of T2DM, when compared with the subjects with $A$-allele. The subjects with rs1726745-G, rs11235972-A and rs1800849-T alleles had also higher serum total and LDL-cholesterol concentrations compared with those carrying the more common alleles. Several variants (rs659366-AA, rs653529-GG, rs15763-AA and rs1726745-GG) were associated with lower abdominal obesity indices, at baseline and longitudinally.

\section{Competing interests}

The authors declare that they have no competing interests.

\section{Authors' contributions}

TS participated in designing and performing the genotyping and statistical analysis and drafted the manuscript; LP participated in designing the genetic studies and haplotype analysis and writing the manuscript; AMT and MK participated in statistical analysis and revising the manuscript; JL, JGE, TTV, SA, PIP, SKK, and ML contributed to study design and coordination and revised the manuscript; JT and MU are the principal investigators of the study and participated in writing the manuscript. All authors read and approved the final manuscript.

\section{Acknowledgements}

This work has been financially supported by grants from the Academy of Finland (no. 40758 to M.U.; 38387 and 46558 to J.T.; 73566 to S.K-K.), the EVO-fund of the Kuopio University Hospital (no. 5179 and 5198 to M.U.), the Ministry of Education of Finland, and the Finnish Diabetes Research Foundation, Yrjö Jahnsson Foundation, Juho Vainio Foundation, Sigrid Juselius Foundation and Finnish Cultural Foundation. The technical assistance of Minna Kiuttu, Tuomas Mäkinen and Päivi Turunen is acknowledged.

\section{References}

I. Chan $C B$, Kashemsant N: Regulation of insulin secretion by uncoupling protein. Biochem Soc Trans 2006, 34(Pt 5):802-805.

2. Arsenijevic D, Onuma $H$, Pecqueur $C$, Raimbault S, Manning BS, Miroux B, Couplan E, Alves-Guerra MC, Goubern M, Surwit R, Bouillaud F, Richard D, Collins S, Ricquier D: Disruption of the uncoupling protein-2 gene in mice reveals a role in immunity and reactive oxygen species production. Nat Genet 2000, 26(4):435-439.

3. De Souza CT, Araujo EP, Stoppiglia LF, Pauli JR, Ropelle E, Rocco SA, Marin RM, Franchini KG, Carvalheira JB, Saad MJ, Boschero AC, Car- neiro EM, Velloso LA: Inhibition of UCP2 expression reverses diet-induced diabetes mellitus by effects on both insulin secretion and action. FASEB J 2007, 2 I (4): I I I53-II 63.

4. Zhang CY, Baffy G, Perret P, Krauss S, Peroni O, Grujic D, Hagen T, Vidal-Puig AJ, Boss O, Kim YB, Zheng XX, Wheeler MB, Shulman GI, Chan $C B$, Lowell $B B$ : Uncoupling protein-2 negatively regulates insulin secretion and is a major link between obesity, beta cell dysfunction, and type 2 diabetes. Cell 200I, 105(6):745-755.

5. Fleury C, Neverova M, Collins S, Raimbault S, Champigny O, LeviMeyrueis C, Bouillaud F, Seldin MF, Surwit RS, Ricquier D, Warden $\mathrm{CH}$ : Uncoupling protein-2: a novel gene linked to obesity and hyperinsulinemia. Nat Genet 1997, I5(3):269-272.

6. Solanes G, Vidal-Puig A, Grujic D, Flier JS, Lowell BB: The human uncoupling protein-3 gene. Genomic structure, chromosomal localization, and genetic basis for short and long form transcripts. J Biol Chem I 997, 272(4 I):25433-25436.

7. Saunders CL, Chiodini BD, Sham P, Lewis CM, Abkevich V, Adeyemo $A A$, de Andrade M, Arya R, Berenson GS, Blangero J, Boehnke M, Borecki IB, Chagnon YC, Chen W, Comuzzie AG, Deng HW, Duggirala R, Feitosa MF, Froguel P, Hanson RL, Hebebrand J, Huezo-Dias P, Kissebah AH, Li W, Luke A, Martin LJ, Nash M, Ohman M, Palmer LJ, Peltonen L, Perola M, Price RA, Redline S, Srinivasan SR, Stern MP, Stone S, Stringham H, Turner S, Wijmenga C, A Collier D: MetaAnalysis of Genome-wide Linkage Studies in BMI and Obesity. Obesity (Silver Spring) 2007, I 5(9):2263-2275.

8. Walder K, Norman RA, Hanson RL, Schrauwen P, Neverova M, Jenkinson CP, Easlick J, Warden CH, Pecqueur C, Raimbault S, Ricquier D, Silver MH, Shuldiner AR, Solanes G, Lowell BB, Chung WK, Leibel RL, Pratley R, Ravussin E: Association between uncoupling protein polymorphisms (UCP2-UCP3) and energy metabolism/obesity in Pima indians. Hum Mol Genet 1998, 7(9): I $431-\mid 435$.

9. Kubota $\mathrm{T}$, Mori $\mathrm{H}$, Tamori $\mathrm{Y}$, Okazawa $\mathrm{H}$, Fukuda $\mathrm{T}$, Miki M, Ito $\mathrm{C}$, Fleury C, Bouillaud F, Kasuga M: Molecular screening of uncoupling protein 2 gene in patients with noninsulin-dependent diabetes mellitus or obesity. J Clin Endocrinol Metab 1998, 83(8):2800-2804.

10. Cassell PG, Neverova M, Janmohamed S, Uwakwe N, Qureshi A, McCarthy MI, Saker PJ, Albon L, Kopelman P, Noonan K, Easlick J, Ramachandran A, Snehalatha C, Pecqueur C, Ricquier D, Warden C, Hitman GA: An uncoupling protein 2 gene variant is associated with a raised body mass index but not Type II diabetes. Diabetologia 1999, 42(6):688-692.

II. Ukkola O, Tremblay A, Sun G, Chagnon YC, Bouchard C: Genetic variation at the uncoupling protein I, 2 and 3 loci and the response to long-term overfeeding. Eur J Clin Nutr 200I, 55(II): $1008-1015$.

12. Rosmond R, Bouchard C, Bjorntorp P: Lack of association between the uncoupling protein-2 Ala55Val gene polymorphism and phenotypic features of the Metabolic Syndrome. Biochim Biophys Acta 2002, I 588(2): $103-105$.

13. Wang H, Chu WS, Lu T, Hasstedt SJ, Kern PA, Elbein SC: Uncoupling protein-2 polymorphisms in type 2 diabetes, obesity, and insulin secretion. Am J Physiol Endocrinol Metab 2004, 286(I):EI-7.

14. Krempler F, Esterbauer H, Weitgasser R, Ebenbichler C, Patsch JR, Miller K, Xie M, Linnemayr V, Oberkofler H, Patsch W: A functional polymorphism in the promoter of UCP2 enhances obesity risk but reduces type 2 diabetes risk in obese middle-aged humans. Diabetes 2002, 5 I (II):333I-3335.

15. Sesti G, Cardellini M, Marini MA, Frontoni S, D'Adamo M, Del Guerra S, Lauro D, De Nicolais P, Sbraccia P, Del Prato S, Gambardella S, Federici M, Marchetti $P$, Lauro $R$ : A common polymorphism in the promoter of UCP2 contributes to the variation in insulin secretion in glucose-tolerant subjects. Diabetes 2003, 52(5): $1280-1283$.

16. Le Fur S, Le Stunff C, Dos Santos C, Bougneres P: The common $866 \mathrm{~g} / \mathrm{a}$ polymorphism in the promoter of uncoupling protein 2 is associated with increased carbohydrate and decreased lipid oxidation in juvenile obesity. Diabetes 2004, 53(I):235-239.

17. Esterbauer H, Schneitler C, Oberkofler H, Ebenbichler C, Paulweber B, Sandhofer F, Ladurner G, Hell E, Strosberg AD, Patsch JR, Krempler F, Patsch W: A common polymorphism in the promoter of UCP2 is associated with decreased risk of obesity in middle-aged humans. Nat Genet 200।, 28(2): I78-183. 
18. Dhamrait SS, Stephens JW, Cooper JA, Acharya J, Mani AR, Moore K, Miller GJ, Humphries SE, Hurel SJ, Montgomery HE: Cardiovascular risk in healthy men and markers of oxidative stress in diabetic men are associated with common variation in the gene for uncoupling protein 2. Eur Heart J 2004, 25(6):468-475.

19. Dalgaard LT, Pedersen O: Uncoupling proteins: functional characteristics and role in the pathogenesis of obesity and Type II diabetes. Diabetologia 200I, 44(8):946-965.

20. Kovacs P, Ma L, Hanson RL, Franks P, Stumvoll M, Bogardus C, Baier LJ: Genetic variation in UCP2 (uncoupling protein-2) is associated with energy metabolism in Pima Indians. Diabetologia 2005, 48(II):2292-2295.

21. Oberkofler H, Iglseder B, Klein K, Unger J, Haltmayer M, Krempler F, Paulweber B, Patsch W: Associations of the UCP2 gene locus with asymptomatic carotid atherosclerosis in middle-aged women. Arterioscler Thromb Vasc Biol 2005, 25(3):604-6I0.

22. Argiles JM, Busquets S, Lopez-Soriano FJ: The role of uncoupling proteins in pathophysiological states. Biochem Biophys Res Commun 2002, 293(4): $1145-1152$.

23. Schrauwen $P$, Hesselink M: UCP2 and UCP3 in muscle controlling body metabolism. J Exp Biol 2002, 205(Pt I 5):2275-2285.

24. Nabben M, Hoeks J: Mitochondrial uncoupling protein 3 and its role in cardiac- and skeletal muscle metabolism. Physiol Behav 2008, 94(2):259-269.

25. Schrauwen P, Xia J, Walder K, Snitker S, Ravussin E: A novel polymorphism in the proximal UCP3 promoter region: effect on skeletal muscle UCP3 mRNA expression and obesity in male non-diabetic Pima Indians. Int J Obes Relat Metab Disord 1999, 23(I 2): | 242-I 245.

26. Schrauwen P, Xia J, Bogardus C, Pratley RE, Ravussin E: Skeletal muscle uncoupling protein 3 expression is a determinant of energy expenditure in Pima Indians. Diabetes 1999, 48(I): I 46-149.

27. Herrmann SM, Wang JG, Staessen JA, Kertmen E, Schmidt-Petersen K, Zidek W, Paul M, Brand E: Uncoupling protein I and 3 polymorphisms are associated with waist-to-hip ratio. J Mol Med 2003, 81 (5):327-332.

28. Meirhaeghe A, Amouyel P, Helbecque N, Cottel D, Otabe S, Froguel $P$, Vasseur $F$ : An uncoupling protein 3 gene polymorphism associated with a lower risk of developing Type II diabetes and with atherogenic lipid profile in a French cohort. Diabetologia 2000, 43(II): I 424-1428.

29. Otabe S, Clement K, Dina C, Pelloux V, Guy-Grand B, Froguel P, Vasseur $F$ : A genetic variation in the $5^{\prime}$ flanking region of the UCP3 gene is associated with body mass index in humans in interaction with physical activity. Diabetologia 2000, 43(2):245-249.

30. Liu YJ, Liu PY, Long J, Lu Y, Elze L, Recker RR, Deng HW: Linkage and association analyses of the UCP3 gene with obesity phenotypes in Caucasian families. Physiol Genomics 2005, 22(2): 197-203.

31. Halsall DJ, Luan J, Saker P, Huxtable S, Farooqi IS, Keogh J, Wareham NJ, O'Rahilly S: Uncoupling protein 3 genetic variants in human obesity: the c-55t promoter polymorphism is negatively correlated with body mass index in a UK Caucasian population. Int J Obes Relat Metab Disord 200I, 25(4):472-477.

32. Hamada T, Kotani K, Fujiwara S, Sano Y, Domichi M, Tsuzaki K, Sakane N: The common -55 C/T polymorphism in the promoter region of the uncoupling protein 3 gene reduces prevalence of obesity and elevates serum high-density lipoprotein cholesterol levels in the general Japanese population. Metabolism 2008, 57(3):410-4I5.

33. van Abeelen AF, de Krom M, Hendriks J, Grobbee DE, Adan RA, Schouw YT van der: Variations in the uncoupling protein-3 gene are associated with specific obesity phenotypes. Eur J Endocrinol 2008, I 58(5):669-676.

34. Cha MH, Shin HD, Kim KS, Lee BH, Yoon Y: The effects of uncoupling protein 3 haplotypes on obesity phenotypes and very low-energy diet-induced changes among overweight Korean female subjects. Metabolism 2006, 55(5):578-586.

35. Dalgaard LT, Sorensen TI, Drivsholm T, Borch-Johnsen K, Andersen T, Hansen T, Pedersen O: A prevalent polymorphism in the promoter of the UCP3 gene and its relationship to body mass index and long term body weight change in the Danish population. J Clin Endocrinol Metab 200I, 86(3): | 398-| 402.
36. de Luis DA, Aller R, Izaola O, Gonzalez Sagrado M, Conde R, Perez Castrillon JL: Lack of association of -55CT polymorphism of UCP3 gene with fat distribution in obese patients. Ann Nutr Metab 2007, 5 I (4):374-378.

37. Uusitupa M, Louheranta A, Lindström J, Valle T, Sundvall J, Eriksson J, Tuomilehto J: The Finnish Diabetes Prevention Study. Br J Nutr 2000, 83(SuppI I):SI37-42

38. Eriksson J, Lindström J, Valle $T$, Aunola $S$, Hämäläinen $H$, llanneParikka P, Keinänen-Kiukaanniemi S, Laakso M, Lauhkonen M, Lehto P, Lehtonen A, Louheranta A, Mannelin M, Martikkala V, Rastas M, Sundvall J, Turpeinen A, Viljanen T, Uusitupa M, Tuomilehto J: Prevention of Type II diabetes in subjects with impaired glucose tolerance: the Diabetes Prevention Study (DPS) in Finland. Study design and I-year interim report on the feasibility of the lifestyle intervention programme. Diabetologia 1999, 42(7):793-80।

39. Tuomilehto J, Lindström J, Eriksson JG, Valle TT, Hämäläinen $H$, llanne-Parikka $P$, Keinänen-Kiukaanniemi $S$, Laakso $M$, Louheranta $A$, Rastas M, Salminen V, Uusitupa M, Finnish Diabetes Prevention Study Group: Prevention of type 2 diabetes mellitus by changes in lifestyle among subjects with impaired glucose tolerance. $\mathrm{N}$ Engl J Med 200I, 344(18): I 343- I350.

40. Albareda M, Rodriguez-Espinosa J, Murugo M, de Leiva A, Corcoy R: Assessment of insulin sensitivity and beta-cell function from measurements in the fasting state and during an oral glucose tolerance test. Diabetologia 2000, 43(I2):|507-I5II.

4I. Friedewald WT, Levy RI, Fredrickson DS: Estimation of the concentration of low-density lipoprotein cholesterol in plasma, without use of the preparative ultracentrifuge. Clin Chem 1972, I 8(6):499-502.

42. de Bakker PI, Yelensky R, Pe'er I, Gabriel SB, Daly MJ, Altshuler D: Efficiency and power in genetic association studies. Nat Genet 2005, 37(II): 12 I7-I223.

43. Cassell PG, Saker PJ, Huxtable SJ, Kousta E, Jackson AE, Hattersley AT, Frayling TM, Walker M, Kopelman PG, Ramachandran A, Snehelatha C, Hitman GA, McCarthy MI: Evidence that single nucleotide polymorphism in the uncoupling protein 3 (UCP3) gene influences fat distribution in women of European and Asian origin. Diabetologia 2000, 43(1 2): I558-1564.

44. Barrett JC, Fry B, Maller J, Daly MJ: Haploview: analysis and visualization of LD and haplotype maps. Bioinformatics 2005, 2I(2):263-265

45. Tregouet DA, Escolano S, Tiret L, Mallet A, Golmard JL: A new algorithm for haplotype-based association analysis: the Stochastic-EM algorithm. Ann Hum Genet 2004, 68(Pt 2): 165-177.

46. Storey JD, Tibshirani R: Statistical significance for genomewide studies. Proc Natl Acad Sci USA 2003, I 00( I 6):9440-9445.

47. Gable DR, Stephens JW, Cooper JA, Miller G], Humphries SE: Variation in the UCP2-UCP3 gene cluster predicts the development of type 2 diabetes in healthy middle-aged men. Diabetes 2006, 55(5): I504-I5II.

48. Damcott CM, Feingold E, Moffett SP, Barmada MM, Marshall JA, Hamman RF, Ferrell RE: Genetic variation in uncoupling protein 3 is associated with dietary intake and body composition in females. Metabolism 2004, 53(4):458-464.

49. Despres JP, Lemieux I, Bergeron J, Pibarot P, Mathieu P, Larose E, Rodes-Cabau J, Bertrand OF, Poirier P: Abdominal obesity and the metabolic syndrome: contribution to global cardiometabolic risk. Arterioscler Thromb Vasc Biol 2008, 28(6): I039-1049.

50. Lee CM, Huxley RR, Wildman RP, Woodward M: Indices of abdominal obesity are better discriminators of cardiovascular risk factors than BMI: a meta-analysis. J Clin Epidemiol 2008, 6I(7):646-653.

5I. Cheurfa N, Dubois-Laforgue D, Ferrarezi DA, Reis AF, Brenner GM, Bouche C, Le Feuvre C, Fumeron F, Timsit J, Marre M, Velho G: The common $-866 \mathrm{G}>\mathrm{A}$ variant in the promoter of UCP2 is associated with decreased risk of coronary artery disease in type 2 diabetic men. Diabetes 2008, 57(4): $1063-1068$.

52. Bulotta A, Ludovico O, Coco A, Di Paola R, Quattrone A, Carella M, Pellegrini F, Prudente S, Trischitta V: The common -866G/A polymorphism in the promoter region of the UCP-2 gene is associated with reduced risk of type 2 diabetes in Caucasians from Italy. J Clin Endocrinol Metab 2005, 90(2): I I 76- I I 80.

53. Sasahara M, Nishi M, Kawashima $H$, Ueda K, Sakagashira S, Furuta $H$, Matsumoto E, Hanabusa T, Sasaki H, Nanjo K: Uncoupling protein 2 promoter polymorphism -866 G/A affects its expression in 
beta-cells and modulates clinical profiles of Japanese type 2 diabetic patients. Diabetes 2004, 53(2):482-485.

54. D'Adamo M, Perego L, Cardellini M, Marini MA, Frontoni $S$, Andreozzi F, Sciacqua A, Lauro D, Sbraccia P, Federici M, Paganelli M, Pontiroli AE, Lauro R, Perticone F, Folli F, Sesti G: The -866A/A genotype in the promoter of the human uncoupling protein 2 gene is associated with insulin resistance and increased risk of type 2 diabetes. Diabetes 2004, 53(7):1905-1910.

55. Cha MH, Kim IC, Kim KS, Kang BK, Choi SM, Yoon Y: Association of UCP2 and UCP3 gene polymorphisms with serum highdensity lipoprotein cholesterol among Korean women. Metabolism 2007, 56(6):806-8I3.

56. Reis AF, Dubois-Laforgue D, Bellanne-Chantelot C, Timsit J, Velho G A polymorphism in the promoter of UCP2 gene modulates lipid levels in patients with type 2 diabetes. Mol Genet Metab 2004, 82(4):339-344.

57. O'Rahilly S: Uncoupling protein 2: Adiposity angel and diabetes devil? Nat Med 200I, 7(7):770-772.

58. Bezaire V, Seifert EL, Harper ME: Uncoupling protein-3: clues in an ongoing mitochondrial mystery. FASEB J 2007, 2I(2):312-324.

\section{Pre-publication history}

The pre-publication history for this paper can be accessed here:

http://www.biomedcentral.com/1471-2350/10/94/pre pub

Publish with Bio Med Central and every scientist can read your work free of charge

"BioMed Central will be the most significant development for disseminating the results of biomedical research in our lifetime."

Sir Paul Nurse, Cancer Research UK

Your research papers will be:

- available free of charge to the entire biomedical community

- peer reviewed and published immediately upon acceptance

- cited in PubMed and archived on PubMed Central

- yours - you keep the copyright

Submit your manuscript here:

http://www.biomedcentral.com/info/publishing_adv.asp 